\title{
A Study on the Extent of Agricultural Financing by the Lead Bank Scheme in Bargarh District of Odisha, India
}

\author{
Debabrata Swain* and Mukesh Kumar Maurya \\ Department of Agricultural Economics, Naini Agricultural Institute, \\ SHUATS, Prayagraj, India \\ *Corresponding author
}

\section{A B S T R A C T}

\section{Keywords}

Lead Bank Scheme,

Financing,

Borrowers,

Defaulters, Bargarh

District

Article Info

Accepted:

15 October 2020

Available Online:

10 November 2020
Agriculture is the backbone of our country, more than $70 \%$ population of our country are dependent on agriculture and it has significant contribution towards our GDP. There are various Innovative, Novel and Planed Schemes and programmes have been designed and implemented, among them Lead Bank Scheme is one the main scheme which plays an important role in the maintain the rural economy of the district. Lead bank is mainly involved in financing towards agriculture sector in the district and also monitors the timely supply and distribution of credit to the farmers mainly for the agriculture operations in the remote rural areas of the district. The study gives clear information about the extent of agriculture financing by the Lead Bank scheme in Bargarh district of Odisha.

\section{Introduction}

Agriculture is an important sector of India economy. New technologies of agricultural production confirm the beginning of new era of modern farming and end of traditional one. Obviously, modern farming requires more finance input which cannot be met fully from personal savings. India, multiagency approach has been recognized to provide credit to the farmers for fulfilment of their requirements. Agriculture plays a very important role in the economy of our country as compare to other sectors but still is being highly neglected, the
Indian banking sector plays an important role in development of Agriculture sector by financing to the agriculture sector. Before nationalization of banks only Industrial sector take the advantage of bank and its services and agriculture sector was highly neglected and there is no upliftment in the rural economy of the country.

A committee was setup under the recommendation of D.R Gadgil and he proposed Area Approach. In 1969 R.B.I set up a committee under the leadership of Shri F.K.F. Nariman who give Lead Bank scheme 
on the basis of Area Approach and to came into force on 1969, the, main aim of the Lead Bank scheme is to reduce Regional Imbalances in the District and setup new branches in rural area and to increase financing in the rural areas especially in the agriculture sector and adequate supply of credit the farmers by the joint coordination between other Banks and Financial Institutions for the development of the Rural Economy.

\section{Materials and Methods}

Bargarh district was selected purposively for the study, as for every district there is a Lead bank and for Bargarh districts the Lead bank is State Bank of India (S.B.I).

Out of 15 blocks of Bargarh District, Barpali block was selected purposively because it has more number of populations as compare to other blocks of Bargarh district and it is a big block as compare to other block. A complete list of all villages was obtained from the selected block and then 5\% of villages from the block was selected randomly for the present study and 5 selected villages was taken for study.

The time series data of 10 years was collected from the lead bank (S.B.I) the data was collected from Various sources of the annual reports of the bank records, through personal visit method from the State Bank of India, Bargarh which is working as a Lead Bank in Bargarh district.

For studying the growth in advances made and deposit the Regression Analysis of the following simple linear type used i.e.

$\mathrm{Y}=\mathrm{a}+\mathrm{bX}$

$\mathrm{Y}=$ dependent variable (advances/ deposits)

$\mathrm{a}=$ intercept of constant $b=$ trend of regression coefficient

$\mathrm{X}=$ independent variable (time in years)

The collected data was Compiled, Tabulated, and Analysed following the Mean, Percentage and Relative Change method.

\section{Mean}

To calculate the mean value

$\bar{x}=\frac{\sum x_{i}}{n}$

\section{Percentage value}

$\mathrm{P}=\mathrm{X} / \mathrm{n} \times 100$

\section{Results and Discussion}

\section{Distribution of lead bank advances to agriculture and other sectors}

The analysis of the data related to the other objectives of this study has been made to find the progress of credit advanced by the farm financing agencies in the lead district. The performance of the lead bank scheme in Bargarh district from 2010-2019 showed that much head way in disbursement of credit has been achieved by the banking sector in Bargarh district. The analysis of data in respect to total advances other advances and agricultural advances from 2010-2019in the district.

As shown in the table 1 that expansion of agricultural credit increased in the succeeding year / period. Data reveals that he proportion of agricultural advances to the total advances increased from $35.87 \%$ in 2010 to $46.98 \%$ in 2019.

The share of other advances to total advances declined sharply during the period from $49.19 \%$ to $39.69 \%$ the growth in total advances was $6.48 \%$ with the relative change 
of $124.18 \%$ similarly the growth in agricultural advances was $193.61 \%$ in relative terms and $10.49 \%$ in terms of growth arte. The relative change in advance to other sectors was $80.88 \%$ with growth rate of 4.26 which is highly significant.

The above results revealed that the growth in agricultural advances was higher as compared to growth in other advances; this may be a good sign of financing for agriculture sector after implantation of.

Lead bank scheme. Similarly if we look at the percentage share of agriculture and other advances over the years it shares near 50$50 \%$.

\section{Branch wise agricultural advances by the lead bank}

The per branch agricultural as well as other advances have been increased during last one decided by the branches operating under the lead bank scheme but the relative change was higher for agricultural sector as compared to advance to other sectors

The per branch total advances was 44 lakh during 2010 which increase to 90 lakh during 2019, similarly it was 17.89 lakh and 45.92 lakh during 2010 and 2019 for agricultural sector respectively (Table 2 ).

Table.1 Increase of agricultural advances over the total and other advances provided by the lead bank (Rs in thousands)

\begin{tabular}{|c|c|c|c|c|c|}
\hline \multirow[t]{2}{*}{ YEAR } & \multirow{2}{*}{$\begin{array}{l}\text { TOTAL ADVANCES } \\
\begin{array}{|c}\text { AMOUNT } \\
\end{array}\end{array}$} & \multicolumn{2}{|c|}{$\begin{array}{l}\text { AGRICULTURAL } \\
\text { ADVANCES }\end{array}$} & \multicolumn{2}{|c|}{ OTHER ADVANCES } \\
\hline & & AMOUNT & $\%$ & AMOUNT & $\%$ \\
\hline 2010 & 669644 & \multicolumn{2}{|l|}{24024135.87} & 329403 & 49.19 \\
\hline 2011 & 792310 & 272538 & 34.39 & 419772 & 52.98 \\
\hline 2012 & 849303 & 281398 & 33.13 & 467905 & 55.09 \\
\hline 2013 & 936486 & 322329 & 34.41 & 514157 & 54.90 \\
\hline 2014 & 924774 & 359533 & 38.87 & \multicolumn{2}{|l|}{465241} \\
\hline 2015 & 1091449 & 392728 & 35.98 & 598721 & 54.85 \\
\hline 2016 & 1179118 & 514288 & 43.61 & 564830 & 47.90 \\
\hline 2017 & 1381039 & 593855 & 43.00 & 687184 & 49.75 \\
\hline 2018 & 1186469 & 692946 & 58.40 & 393523 & 33.16 \\
\hline 2019 & 1501217 & 705382 & 46.98 & 595835 & 39.69 \\
\hline Percentage change & $124.18 \%$ & $193.61 \%$ & & $80.88 \%$ & \\
\hline Growth percentage & 5.48 & 9.49 & & 3.26 & \\
\hline
\end{tabular}

Table.2 Development of Agricultural Advances per branch under Lead Bank Scheme (Rs.Lakh/branch)

\begin{tabular}{|c|c|c|c|}
\hline YEAR & $\begin{array}{l}\text { TOTAL } \\
\text { ADVANCES }\end{array}$ & $\begin{array}{l}\text { AGRICULTURE } \\
\text { ADVANCES }\end{array}$ & OTHER ADVANCES \\
\hline 2010 & 44.00 & 17.89 & 26.11 \\
\hline 2019 & 90.00 & 45.92 & 44.08 \\
\hline $\begin{array}{l}\text { PERCENTAGE CHANGE } \\
(\%)\end{array}$ & 104.54 & 156.67 & 68.24 \\
\hline
\end{tabular}


Table.3 Total deposit, total advances to agricultural sector, advances and their ratio (Rs in Thousands)

\begin{tabular}{|c|c|c|c|c|c|c|c|}
\hline \multirow[t]{2}{*}{ YEAR } & \multicolumn{2}{|c|}{ Total deposit } & \multirow{3}{*}{$\begin{array}{l}\text { Total } \\
\text { advance } \\
\text { amount }\end{array}$} & \multicolumn{2}{|c|}{$\begin{array}{l}\text { Total Agriculture } \\
\text { Advances }\end{array}$} & \multicolumn{2}{|l|}{ Proportion } \\
\hline & Amount & $\%$ & & Amount & $\%$ & $\begin{array}{l}\text { Total } \\
\text { advances to } \\
\text { total deosit }\end{array}$ & $\begin{array}{l}\text { Agriculture } \\
\text { advances to } \\
\text { total deposit }\end{array}$ \\
\hline 2010 & 876619 & 6.85 & & 240241 & 5.49 & 76.38 & 27.40 \\
\hline 2011 & 981713 & 7.67 & 792310 & 272538 & 6.22 & 80.70 & 27.76 \\
\hline 2012 & 1018867 & 7.96 & 849303 & 281398 & 6.43 & 83.35 & 27.61 \\
\hline 2013 & 1076692 & 8.42 & 936486 & 322329 & 7.36 & 86.98 & 29.93 \\
\hline 2014 & 1195640 & 9.35 & 924744 & 359533 & 8.21 & 77.34 & 30.07 \\
\hline 2015 & 1362384 & 10.65 & 1091449 & 392728 & 8.97 & 80.11 & 28.82 \\
\hline 2016 & 1440102 & 11.26 & 1179118 & 514288 & 11.75 & 81.87 & 35.71 \\
\hline 2017 & 1558292 & 12.18 & 1381039 & 593855 & 13.57 & 88.62 & 38.10 \\
\hline 2018 & 1659606 & 12.98 & 1186469 & 692946 & 15.83 & 71.49 & 41.75 \\
\hline 2019 & 1615449 & 12.63 & 1501217 & 705382 & 16.12 & 92.92 & 43.66 \\
\hline TOTAL & $1,27,85301$ & 100 & $98,42,165$ & $41,34,997$ & 100 & 76.98 & 32.34 \\
\hline
\end{tabular}

Table.4 Numbers of borrowers according to size of land holding

\begin{tabular}{|l|l|l|l|l|l|l|l|l|l|}
\hline \multicolumn{2}{|c|}{ Year } & \multicolumn{3}{c|}{ Small } & \multicolumn{3}{c|}{ medium } & \multicolumn{3}{c|}{ large } & \multicolumn{2}{c|}{ total } \\
\hline SI.No & & NUMBER & $\%$ & NUMBER & $\%$ & NUMBER & $\%$ & NUMBER & $\%$ \\
\hline $\mathbf{1}$ & 2010 & 201 & 48 & 109 & 26 & 107 & 26 & 417 & 100 \\
\hline $\mathbf{2}$ & 2011 & 213 & 50 & 112 & 27 & 97 & 23 & 422 & 100 \\
\hline $\mathbf{3}$ & 2012 & 240 & 51 & 124 & 27 & 103 & 22 & 467 & 100 \\
\hline $\mathbf{4}$ & 2013 & 233 & 49 & 128 & 27 & 115 & 24 & 476 & 100 \\
\hline $\mathbf{5}$ & 2014 & 210 & 49 & 116 & 27 & 101 & 24 & 427 & 100 \\
\hline $\mathbf{6}$ & 2015 & 228 & 47 & 130 & 27 & 125 & 26 & 483 & 100 \\
\hline $\mathbf{7}$ & 2016 & 244 & 47 & 153 & 30 & 118 & 23 & 515 & 100 \\
\hline $\mathbf{8}$ & 2017 & 238 & 42 & 203 & 35 & 132 & 23 & 573 & 100 \\
\hline $\mathbf{9}$ & 2018 & 240 & 41 & 213 & 36 & 137 & 23 & 590 & 100 \\
\hline $\mathbf{1 0}$ & 2019 & 256 & 44 & 196 & 34 & 127 & 22 & 578 & 100 \\
\hline
\end{tabular}


Table.5 Number of defaulters under different groups of holding

\begin{tabular}{|c|c|c|c|c|c|c|c|c|}
\hline \multirow[t]{2}{*}{$\begin{array}{l}\text { Size of lannd holding } \\
\text { in acre }\end{array}$} & \multicolumn{2}{|c|}{ Borrowers } & \multicolumn{2}{|c|}{$\begin{array}{c}\text { Number of } \\
\text { defaulters have } \\
\text { the repayment } \\
\text { capacity }\end{array}$} & \multicolumn{2}{|c|}{$\begin{array}{c}\text { Number of } \\
\text { borrowers dont } \\
\text { have repayment } \\
\text { capacity }\end{array}$} & \multicolumn{2}{|c|}{$\begin{array}{c}\text { Total number of } \\
\text { defaulters }\end{array}$} \\
\hline & NUN & \begin{tabular}{l|l}
$\mathrm{R}$ & $\%$ \\
\end{tabular} & NUN & \begin{tabular}{l|l}
2 & $\%$ \\
\end{tabular} & NUI & \begin{tabular}{l|l} 
ER & $\%$ \\
\end{tabular} & NUMBER & $\%$ \\
\hline $\begin{array}{l}\text { Small } \\
\text { Farmers }\end{array}$ & 2302 & 46.52 & 670 & 58.77 & 305 & 52.31 & 970 & 56.29 \\
\hline $\begin{array}{c}\text { Medium } \\
\text { farmers }\end{array}$ & 1484 & 29.99 & 250 & 21.92 & 95 & 16.29 & 351 & 20.37 \\
\hline $\begin{array}{l}\text { Large } \\
\text { Farmers }\end{array}$ & 1162 & 23.48 & 220 & 19.29 & 183 & 31.38 & 402 & 23.3 \\
\hline Total & 4948 & 100 & 1140 & 100 & 583 & 100 & 1723 & 100 \\
\hline
\end{tabular}

\section{Deposits / Advances ratios}

In this study an attempt was also made to estimate the proportions of the total deposits top total advances and the total advances to total agricultural advances for different years the combined period of 10 years from 2010 to 2019. Out of total deposits of all banks 76.98 percent were only advanced as credit in the Bargarh district. Thus the amount collected in the form of deposits by these banks in every district were not distributed fully in there form of advance for developing the district economy by these credit institutions (Table 3 ).

This is not a healthy trend because this developing as a gap between mobilization of deposits and distribution of advance by the commercial banking systems at district level, the fight of resources from the district mobilized and there is more productive areas at the cost of development of that particular district is a disquieting sign of neglecting the development concerned to invest more in the same area from where the resources collected from 2016 onwards the increasing proportion of agricultural advances to the total deposits indicated the higher potentiality of agriculture growth in the Bargarh district by paying more attention by the banks (Table 4).
The growth in membership / borrowers of the lead bank

The members of State bank of India in Bargarh district are classified in to three size group of land holding as small medium, and large.

4 shows the overall borrowers were increased gradually since the year 2010-17but a slightly decreasing trend was observed in year 2019, an increasing pattern was found in small group farmers whereas, in case of medium and large group there was slightly decreasing trend was observed in the year 2019.Thus maximum borrowers belonged to small followed by medium group farmers.

\section{Defaulters of the lead bank}

Table 5 shows the Defaulters according to the different size of land holding. The term repayment capacity is defined the excess o income over the payment and expenditure on the basis of analysis of data of 4948 borrowers he following statements are given

The data shows that 1723 farmers were defaulters in which 23.00 percentage defaulters have the repayment capacity but 
they are not depositing credits and $11.78 \%$ were those number of defaulters who don't have repayment capacity. The table 5 shows that 56.29 defaulters fall in the capacity of those who have small group of land holding. It further reveals that 20.37 percent defaulters fall in medium and 23.33 percent in large group.

In conclusions the realistic policy should be adopted by the lead bank and it should perform more responsible function for adequate supply of funds. The study reveals that the extent of agriculture financing by the Lead Bank scheme in Agriculture Sector was initially slow but it has been growth tremendously over years. Awareness about borrower ethics should be introduced by the Lead Bank for prop repayment of loans. The overall performance of the Lead Bank scheme in financing the Agriculture sector was appreciable.

\section{References}

Mundimani, P.S. (2005) Financing of agriculture by commercial banks in Dharwad district: Emerging issues. Indian Journal of Agricultural Economics, 60: 384.

Pandey, R.K. (1997). Financing of priority sector by commercial banks in India. Recent progress. Argil. Banker, 20: 39-40.

Mishra, R.K. (2005). Impact of institutional finance on Farm income and Productivity: A case study of Orissa. Indian Journal of Agricultural
Economics, 60: 361.

Thorat, V.A., Talker, S.N. and Bagade, S.R. (2005). Determinants of borrowings from the Primary Agricultural Cooperative Societies. Indian Journal of Agricultural Economics, 60: 368.

Goyal, S.K. And Pandey, R.H. (1991). An analysis of defaults of crop loan in primary agriculture cooperative credit and service societies in Haryana Argil. Banker, 14: 24-31.

Chakarborty, D.K. (2005). Credit and the Agricultural sector: Study of the North eastern India. Indian Journal of Agricultural Economics, 60: 390.

George, K.M. and Babuk S. (1996). Overdue pattern of PACS: A micro level analysis. Agril. Banker, 20(2): 29-37.

Gopalkrishna, B.K. (1996). Credit and recovery performance of institutional finance under agriculture sector. Agril. Banker, 20(2): 27-31

Hatai, L.D., Singh, H.P., Sen, C. and Dixit, R.S. (2005). An economic analysis of agriculture credit and over dues in different regions of Uttar Pradesh. Indian Journal of Agricultural Economics, 60: 364.

Kareemulla, K. (2005). Institutional credit flow to agriculture and farm indebtedness in Uttar Pradesh. Indian Journal of Agricultural Economics, 60: 364.

Kataria, P and Chahal, S.S. (2005). Rural credit delivery system in India: Performance appraisal o0f scheduled commercial banks. Indian journal of agricultural Economics, 60:364.

\section{How to cite this article:}

Debabrata Swain and Mukesh Kumar Maurya. 2020. A Study on the Extent of Agricultural Financing by the Lead Bank Scheme in Bargarh District of Odisha. Int.J.Curr.Microbiol.App.Sci. 9(11): 2208-2213. doi: https://doi.org/10.20546/ijcmas.2020.911.264 